\title{
A Tale of Two Taxes: Clean Energy Act 2011 (Cth) V Renewable Energy (Electricity) Act 2000 (Cth)
}

\author{
Alexander Robert ('Lex') Fullarton \\ Curtin University
}

This paper investigates what is considered to be carbon tax legislation and defines a carbon tax. It examines the Australian Renewable Energy (Electricity) Act 2000 (Cth) (REE Act) and concludes that the REE Act is a form of carbon tax. The tax is levied by way of a renewable energy certificates (RECs) system wherein RECs are created by the operators of renewable energy generation installations and sold to the suppliers of fossil fuelled generated electricity. The RECs are used as tokens to pay Australia's carbon tax. The tax system acts to support the burgeoning renewable energy industry in Australia.

\section{INTRODUCTION}

Before beginning a detailed examination of Australia's carbon taxing systems the concept of a carbon tax is placed within the broader scope of the overall concept of taxes. Taxes, tithes, levies, scutages - and like contributions by the people to emperors, kings, lords and other forms of governing bodies - have existed since humankind moved from Mesolithic societies to the more complex social structures of the biblical era.

The definition of tax is well settled, yet it is redefined here to place the concept of carbon taxes within the broader scope of taxes generally. Therefore, this paper considers the definition of tax within the parameters of the Australian Constitution, adopted at Federation ${ }^{1}$.

It then considers taxes on greenhouse gas emissions, which are commonly referred to as 'carbon taxes', and introduces the current Australian energy legislation aimed at reducing greenhouse gas emissions to combat climate change.

To begin its consideration of the definition of tax this paper briefly looks at previously published literature to highlight Australian cases that are relevant in determining a clear definition of a carbon tax.

Burton (2007) places the concept of a tax as being between a sale — which is a contract for the exchange of goods or services, and a - which is the taking property with intention to deprive the individual of his property totally and permanently for no return ${ }^{2}$.

He states that "for many liberals, private property pre-exists any claim of the state and so a tax is an imposition upon individuals. This imposition might be cast in terms of an exchange contract - 'taxes are what you pay for civilized society",3. Or it might be conceived in terms of a compulsory exaction which does not necessarily purchase public services - theft $^{4}$. Under this view, the onus is upon the state to show why it should receive some of the taxpayer's private property. Thus tax legislation is to be read restrictively because the government is compulsorily acquiring private property and has ample resources to accurately define the extent to which it will exact tax from its subjects" (Burton 2007). 
Woellner et al. (1997, p.8) consider the definition of the Concise Oxford Dictionary as a basis for their perspective on taxation. They use the definition that tax is a "contribution levied on persons, property or business for the support of government". They also provide a categorisation of direct and indirect taxes, which are further broken down into subcategories according to tax base and application such as direct capital gains taxes and indirect land taxes.

They find that a 'tax' is 'the process of "raising money for the purposes of government by means of contributions from individual persons" (Woellner et al. 1977, p.71).

They support that definition by stating the findings in "MacCormick $v$ Federal Commissioner of Taxation; Camad Investments Pty Ltd v Federal Commissioner of Taxation, Gibbs CJ, Wilson, Deane and Dawson JJ in the High Court identified the following characteristics of a "tax".

- It is a compulsory payment;

- The moneys are raised for government purposes;

- $\quad$ The exactions do not constitute payment for services rendered ${ }^{i}$;

- The payments are not penalties ${ }^{i i}$;

- $\quad$ The exactions are not arbitrary ${ }^{i i}$; and

- The exaction should not be incontestable ${ }^{\text {iv }}$.

Morabito and Barkoczy (1996, p 47) also consider the findings of Latham CJ in Matthews $v$ Chicory Marketing Board (Vic) (1938) 60 CLR 263 for a definition of tax, although they caveat that his Honour's finding is not exhaustive. They point to the finding in Air Caledonie International $v$ The Commonwealth (1988) 165 CLR 462 which states "that [the general statement of Latham CJ] should not be seen as providing an exhaustive definition of a tax."

Twenty years later, in 2017, Deutsch et al (2017) continued to share that general view, but stated that "there is no exhaustive definition of "tax", although Latham CJ's statement in Matthews $v$ Chicory Marketing Board (Vic) (1938) 60 CLR 263 at 276 that a tax is "a compulsory exaction of money by a public authority for public purposes, enforceable by law, and is not a payment for services rendered" is seen as a useful guide" (Deustch et al. 2017, para 1020).

An economic perspective is provided by Woellner et al's consideration of Allan's "wider view that a tax is "any leakage from the circular flow of income into the public sector, excepting loan transactions and direct payments for publicly produced goods and services up to the cost of producing these goods and services" (Allan, 1971, 24-27).

The generally accepted model of the economic flow is that tax is paid directly to government. For clarity, the following diagram of the economic circular flow is provided to illustrate that government revenue and expenditure is generally considered as separate economic functions. 
FIGURE 1

\section{BASIC ECONOMIC FLOW DIAGRAM}

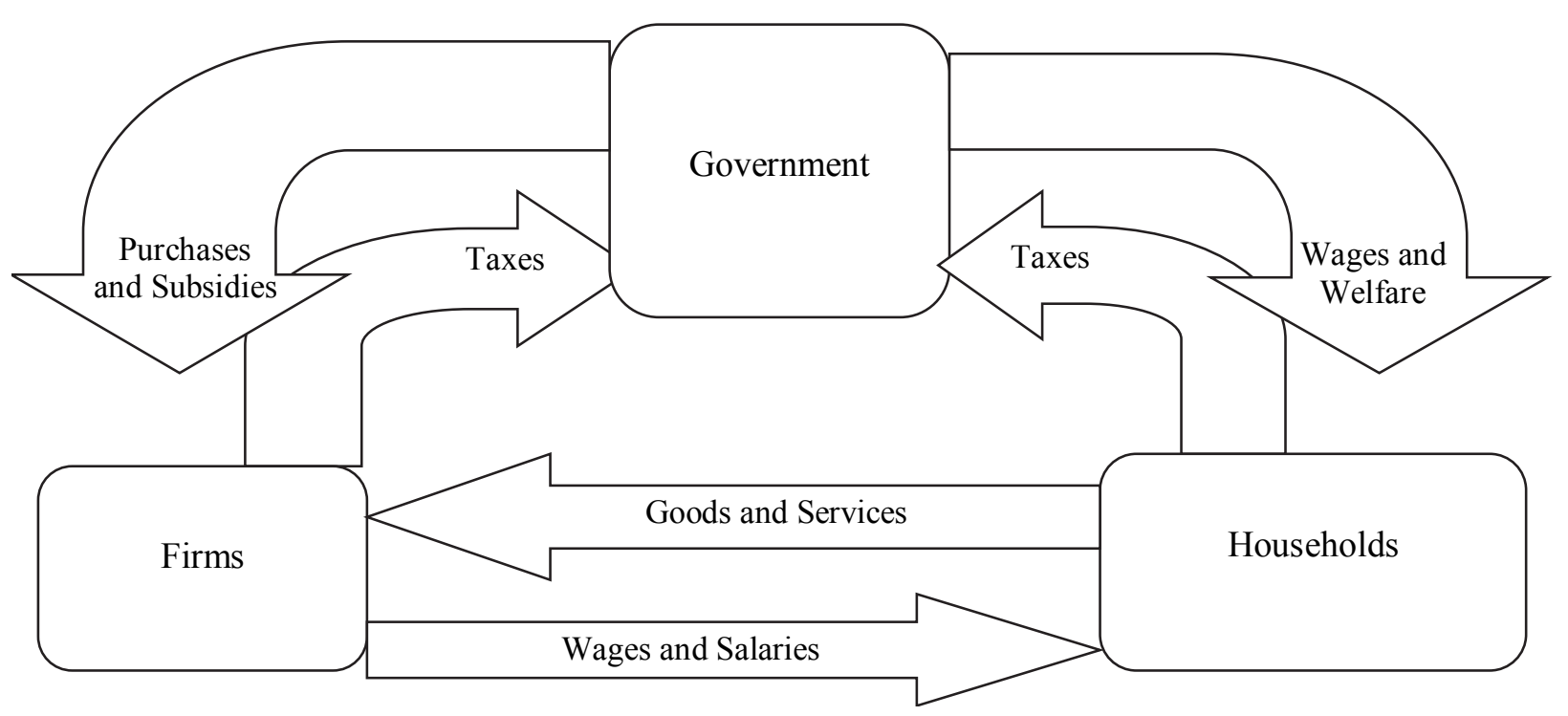

For simplicity, Figure 1 ignores the purchase of goods and services from government trading enterprises by households and firms.

This broad economic view of taxation is particularly relevant to this examination, as the concept of trading renewable energy certificates, under the provisions of the REE Act, circumvents government revenue and expenditure fiscal organisations.

In the case of the REE Act, the flow of monies payable under its provisions comes directly from liable parties (fossil fuel generators) to subsidised industries (renewable energy generators), and are generally not paid to, through or from, government bodies. Nonetheless payments made by liable parties to renewable energy generators are at the direction of the government and enforced by financial penalties. They may, therefore be considered as a tax.

To further develop the concept of a carbon tax, a number of dictionary meanings of tax are also considered in order to provide a working concept of tax. The examination also considers cases which have been relied upon by those dictionaries to define the concept of a tax.

In order to further narrow the concept of tax, to focus on the definition of a carbon tax, the examination also looks at a class of tax relevant to this discussion - 'excises'. Excises are considered to be a class of tax levied on the value of goods.

The official dictionary for the Australian Guide to Legal Citation (Melbourne University Law Review, 2018), the Macquarie Dictionary, defines tax firstly as "a compulsory monetary contribution demanded by a government for its support and levied on incomes, property, goods purchased, etc" and, secondly, "a burden-some charge, obligation, duty or demand" (Yallop et al. 2006, p 1255). Further, it defines a subset of taxes - excises - as being "a tax or duty on certain commodities, such as spirits, tobacco, etc., levied on their manufacture, sale, or consumption within a country" (Yallop et al. 2006, p 410).

Webster's Dictionary defines a tax to be "a compulsory payment of a percentage of income, property value, sales price, etc. for the support of a government" (McKechnie (ed), 1956, p 1869). This paper focuses on the tax on a good, that is the sale of fossil fuel sourced electricity, and therefore it is of particular relevance that the dictionary also defines an excise to be "a tax; a tax or duty imposed on the manufacture, sale, or consumption of certain commodities within a country, as tobacco, spirits etc" (McKechnie (ed), 1956, p 637). 
The Oxford Dictionary defines tax simply as "a contribution to state revenue, compulsorily levied on people, businesses, property, income, commodities, transactions etc" (Stevenson (ed), 2007, p 3189). It too defines an excise as the imposition of a duty "duty on (a thing)" (Stevenson (ed), 2007, p 886).

The word 'thing' is very broad but it is assumed in this context to mean a tangible product rather than a service.

Butterworth's Concise Australian Legal Dictionary defines taxation as "a compulsory exaction of money by a government for public services, being neither a pecuniary penalty nor a fee for services rendered" (Butt, 2004, p 423). It looks to the findings of previously litigated cases to support its definition and specifically refers to Latham CJ's statement in Matthews $v$ Chicory Marketing Board (Vic) (Matthews Case) (1938) 60 CLR 263.

The Matthews Case considered the application of a state levy on goods harvested in Victoria, and traded interstate. The case considered the levy on the producers of chicory at the rate of two Australian Pounds per acre, to be an excise. Therefore the tax was in contravention of s 92 of The Australian Constitution $^{6}$ and therefore beyond the jurisdiction of the State of Victoria.

However it is noted that the REE Act is Commonwealth Legislation, and, therefore, the finding in the Matthews Case is not applicable to this discussion but adds to the overall definition of tax and introduces the element of 'legality' to the definition of a tax.

Despite that, Latham CJ's statement holds aspects which are significant to this paper. Firstly he clarified a tax as being "a compulsory exaction of money by a public authority for public purposes, enforceable by law, and is not a payment for services rendered" (Matthews Case). Secondly, he considered the state levy to be a tax, and specifically an excise. He stated "a tax possessing the other attributes mentioned in the passage [in Peterswald $v$. Bartley] which I have quoted may be an excise duty if it is imposed upon the sale or consumption of goods" (Matthews Case).

In 2003, in Bartlett $v$ Commissioner of Taxation [2003] FCA 1125 the Federal court considered the definition of tax as being that contained in s 995-1 of the Income Tax Assessment Act (1997) Cth (ITAA 1997).

Section 995-1 states that a tax means (a) income tax imposed by the Income Tax Act 1986, as assessed under this Act; or (b) income tax imposed as such by any other Act, as assessed under this Act. The definition of a tax prescribed by s 995-1 means a tax. The circular definition given in the ITAA 1997 is not overly helpful.

However this paper considers that the definitions presented focus on tax to be a compulsory payment pursuant to government legislation, therefore defines a tax accordingly as being a compulsory payment. Further, given that carbon taxes are placed on a product or good, and that a tax on goods is a class of tax referred to as an excise, this paper this paper moves to consider the category of excises (Woellner et al. 1977).

Butterworth's definition of excise appears more specific than that put forward by Latham CJ, by defining an excise as "a tax on goods levied at some point in their production or distribution which has the effect of increasing the price of goods supplied to the customer" (Butt, 2004, p 159). The definition also refers to Capital Duplicators Pty Ltd v Australian Capital Territory (No2) (1993) 173 CLR 561 for support.

As with the Matthews Case, the finding in Capital Duplicators Pty Ltd v Australian Capital Territory (No2) was that the excise levied by the Australian Capital Territory was invalid pursuant to s 90 of The Australian Constitution. Despite the focus on unlawful excises, the finding is used to support Butterworth's definition that a tax imposed on a good is an excise.

In conclusion, therefore, to establish a working definition of tax for the purpose of this paper, this discussion concludes that for a payment to be a tax, it is:

- A compulsory payment, yielding up of property, or performance of services, at the direction of a government, for no corresponding consideration or form in return; and

- A tax cannot be unlawful, unjustifiably extortionate, or a penalty. 
An unjustifiable extortionate levy would become unlawful, or a penalty, and would therefore not be a tax. Such penalties have been levied on certain classes of persons throughout the ages. They amount to persecution of particular groups of people, and as such as examination is beyond the scope of this paper.

The following section moves to marrow the scope of the broad definition of taxes to examine the class of tax which is specific to the focus of this paper-carbon taxes.

\section{Carbon Taxes}

The lack of direct government fiscal involvement in the financial transactions under the provisions of the REE Act, may lead to a belief that trade in renewable energy certificates is not a taxation system in a traditional sense. This section aims to define the concept of a carbon tax and to place the provisions of the REE Act within the scope of a carbon taxing system. To do that it focuses on the comprehensive analysis of the economic aspects of climate change conducted by the Head of the UK Government Economic Service, Nicholas Stern - The Stern Review (Stern, 2007).

Under the REE Act mechanism registered renewable energy certificates are created by registered renewable energy generators and sold to fossil fuel electricity wholesalers in a market place according to ordinary economic concepts. The renewable energy certificates are then surrendered to the government in accordance with a ratio set by regulation - the Renewable Energy Target (RET).

Weber (2011) views the mechanisms of trading 'green certificates' as different and distinct from 'carbon taxes'. He refers to them as 'cap-and-trade regimes' and points to 'the key feature of the cap-andtrade scheme consist[ing] in the government stipulation of a maximum amount (cap) of carbon dioxide that can be emitted" (Weber, 2011, p 50) to provide that distinction.

However Weber also states that although "[a] generally accepted definition of the term environmental tax is not yet available. The Organisation for Economic Co-operation and Development (OECD) refers to the environmental tax as a tax based on polluting emissions or on disamenities expressed by appropriate methods of measurement or on other parameters such as inputs" (Weber, 2011, p 48).

He further suggests that environmental taxes cover a broad range of everything which affects the environment and "on every possible polluting material" (Weber, 2011, p 48). He states that "taxes on carbon emissions undoubtedly fall under this definition" (Weber, 2011, p 48).

Rivers and Schaufele state that "[c]arbon taxes differ from excise or other consumption taxes in that, by imposing a disincentive on fossil fuel consumption, they are explicitly designed to reduce environmental externalities" (2015, p 24).

In 2007 the United Kingdom commissioned a review on the economic impacts of climate change (the Stern Review) (Stern, 2007). Significantly the review makes the distinction between taxes and tradeable quotas by considering that taxes are a charge levied on volumes of greenhouse gas emissions (Stern, 2007, p 353). Under a carbon tax mechanism there is no limit placed on the volumes of emissions other than to tax them. The goal of reducing emissions is achieved by the economic burden imposed by the cost incurred by the tax (Stern, 2007, p 359).

Alternatively, under a 'cap and trade' mechanism, tradeable quotas fix the volume of emissions, with penalties for exceeding those volumes, and a provision for trading unused quotas for those entities operating below the fixed, or expected emissions, level (Stern, 2007, p 359).

The Stern review states that "[t]axes can set the global price of greenhouse gases, and emitters can then choose how much to emit. Alternatively, a total quota (or ceiling) for global emissions can be set and tradable quotas can then determine market prices" (Stern, 2007, p 354) ${ }^{7}$.

Stern also states that the distinction between a 'carbon tax' and a 'tradeable quota/cap-and-trade' system is that a carbon tax is a levy on greenhouse gas emissions (Stern, 2007, p 362) whereas "In contrast, a quota-based system will not automatically raise revenue unless firms must initially purchase some or all quotas from government in either an auction or a direct sale. In contrast if quotas are allocated for free, then the asset is passed to the private sector and the benefits ultimately accrue to the owners and shareholders of the firms involved"8 (Stern, 2007, p 362). 
Further, Stern questions the economic benefit of free, and tradable, quotas allocated to emitters by the government. He states "In the long term, however, there is little economic justification for such transfers from the public sector to individual firms and their shareholders" "Stern, 2007, p 362).

It is emphasised here that under the provisions of the REE Act emitters are directed to purchase 'green certificates' from renewable energy generators by the government. Therefore the supply of renewable energy certificates is unlimited and not free. Despite the price being set by private contract between buyers and sellers the price is influenced by government (using the RET mechanism) and no cap is placed on greenhouse gas emissions.

That distinction is central to this discussion and therefore this examination makes that same distinction

- a tax is a levy on unlimited emissions - That is a fixed tax emissions charge with unlimited emissions; and

- a carbon trading mechanism that is limited by a fixed allocation of 'green certificates' That is a fixed emissions rate with a penalty for exceeding the fixed allocation. It also facilitates the sale of unconsumed emission permits or certificates.

As illustrated in Figure 2, in standard economic models taxes become public funds as they are paid directly to government. Those funds form part of general revenue and may be applied in any manner that the government sees fit.

Rivers and Schaufele (2015) point out hypothecation of carbon taxes in that revenue generated from them is put towards specific environmental benefits, rather than merely generating general government revenue, which can be applied in any manner the government sees fit. They use the example of fuel taxes to make that distinction. "Revenues from gasoline taxes, for example, are frequently earmarked for road infrastructure, projects which lower the long-run costs of driving. Concentrating on carbon pricing permits us to identify the consumer response to a carbon tax compared with the underlying market price of gasoline when the unambiguous purpose of the policy is to reduce gasoline demand" (Rivers and Schaufele, 2015, p 24).

Rather than using Rivers and Schaufele's (2015) example of road infrastructure, Figure 2 illustrates the outflows of government revenue being directed towards renewable energy generators in the form of subsidies.

\section{FIGURE 2}

\section{CARBON TAX SYSTEM - INCORPORATING RENEWABLE ENERGY SUBSIDIES}

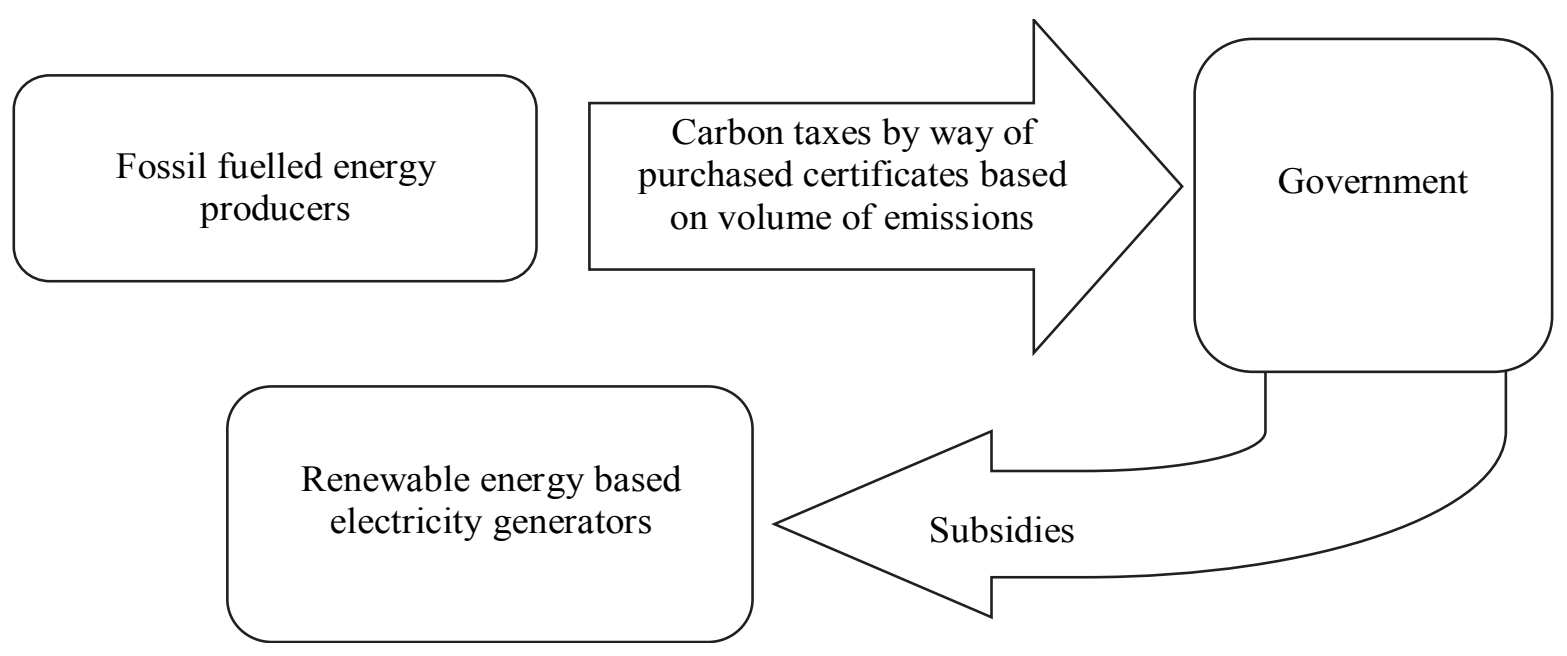

A detailed discussion of subsidies is beyond the scope of this paper, but they are highlighted as background to the discussion later in the REE Act examination. 
However, Stern describes a system of taxation whereby emitters purchase certificates from the government (tax credits) and are permitted to trade excess credits between entities (Stern 2015, p 371). In that way emitters, which achieve greater fuel efficiency than their ceiling quota for emissions, can be rewarded by selling the 'unused' credits to other, less efficient, emitters.

The contribution of each emitter, which is based on the volume of emissions, becomes part of market forces within that economic sector. While trade in credits may take place in a market within the overall energy industry, the entire economic sector is taxed at a fixed rate - the sale price of the credits purchased from the government. Therefore any profit or loss, attributed to the trade in certificates between emitters, does not become part of government revenue.

Stern notes both taxes and tradable quotas can be used to raise public funds. Carbon taxes automatically raise public revenues, but tradable-quota systems only have the potential to raise public revenue if firms have to purchase the quotas from government through a sale or auction (Stern 2015, $\mathrm{p}$ 362).

Further, a tradeable quota system may also function as public funds if the revenue stream flows at the direction of government, albeit not through government. By directing a liable party to pay funds directly to a certain industry, as illustrated in Figure 3, the system operates in the same way as a hypothecated excise $-\mathrm{a}$ tax on one industry to subsidise another.

\section{FIGURE 3}

\section{RENEWABLE ENERGY CERTIFICATES USED AS 'TAX TOKENS'}

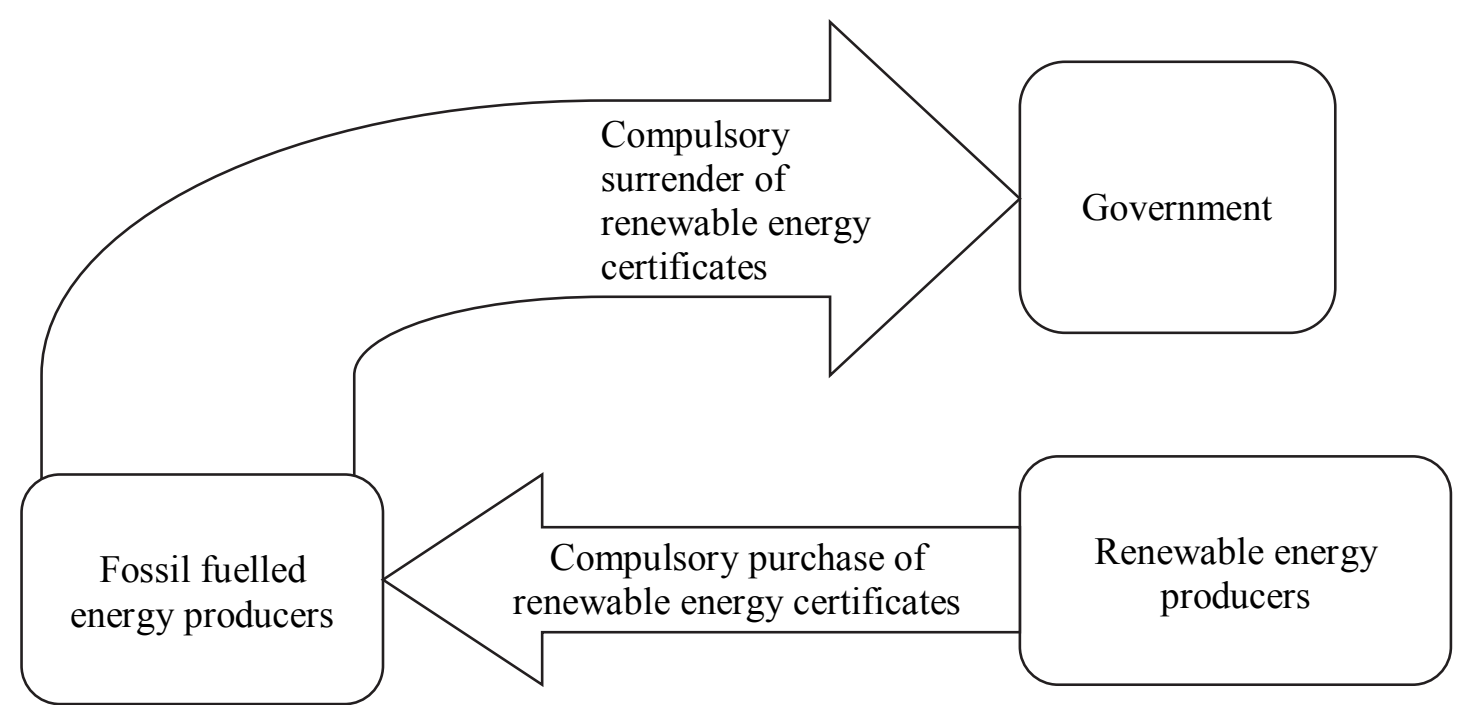

In conclusion, it is apparent that both carbon tax and carbon trading mechanisms can function in almost identical fiscal fashion. The key difference being that carbon taxes form part of general government revenue, which could be applied to any purpose the government sees fit, and that under a carbon trading mechanism such as the REE Act, revenue is directed, or hypothecated, to a specific industry or economic sector.

Figure 4 illustrates how carbon taxes are placed within the overall structure of exactions or taxes from the broad to the specific. Note Figure 4 is for illustration purposes only and is not an exhaustive list. 


\section{FIGURE 4 \\ CARBON TAXES WITHIN THE CATEGORIES OF COMMON TAXES}

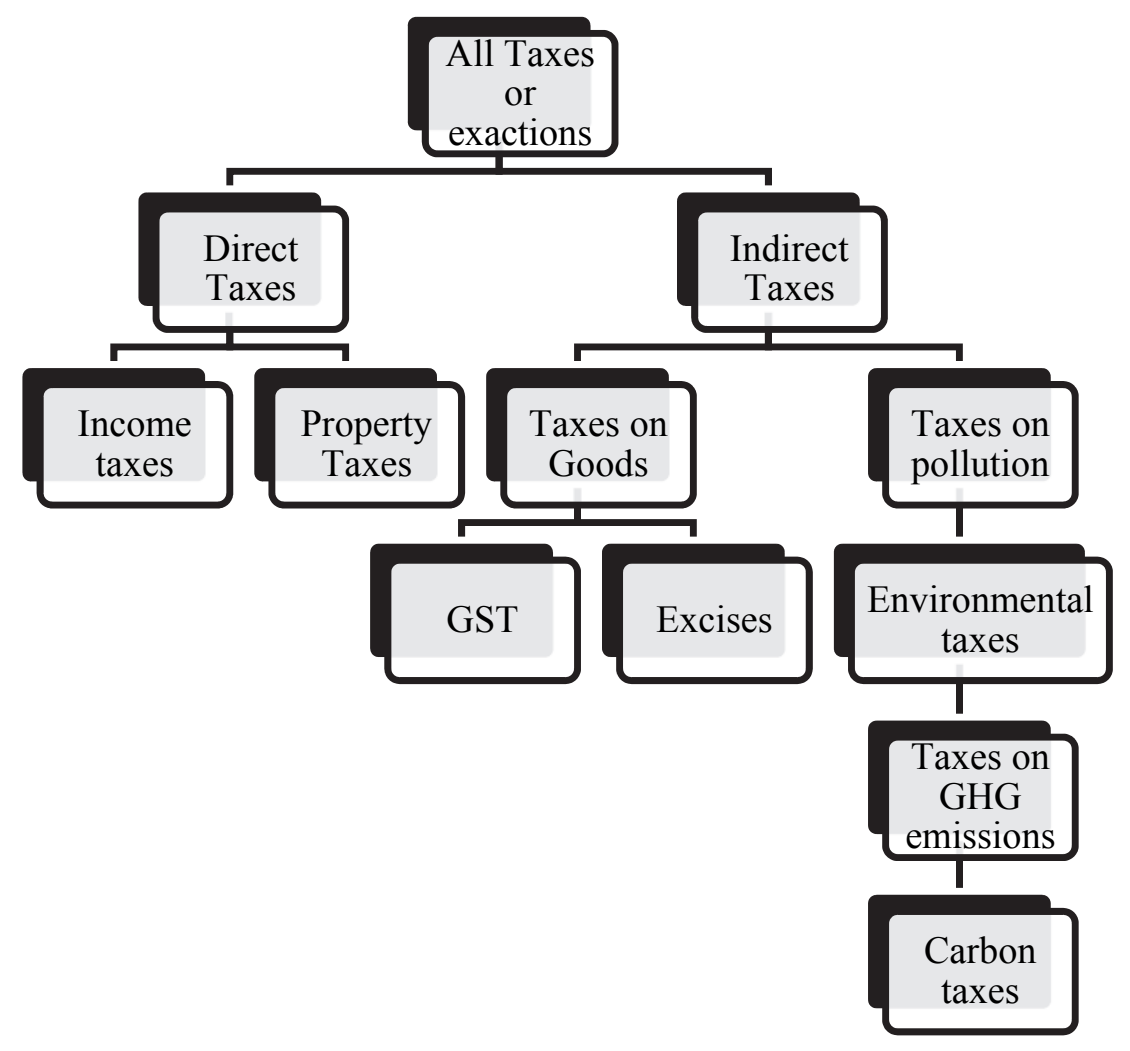

The following sections examine Australia's carbon emissions legislation - the renewable energy legislation, introduced by the Howard Liberal government in 2000; and the CE Act, introduced by the Gillard ALP government in 2011.

\section{Australia's Carbon Taxes}

The purpose of this section is to compare and contrast the two pieces of legislation to identify similarities and differences between them. The intent is to demonstrate that if the CE Act was identified as a 'carbon tax', then the REE Act should also be considered a 'carbon tax'.

Regrettably, the two acts have had little, or no, relevant litigation to clarify or to provide interpretation of meanings or parliamentary intent of provisions within the acts.

To establish the underlying intent of the legislation, and the legislative interpretations, this examination will focus on the Explanatory Memoranda accompanying the bills in Parliament and the legislation itself. The use of extrinsic material and in particular the examination of explanatory memoranda to establish the intent of legislation is supported by the provisions sections $15 \mathrm{AA}, 15 \mathrm{AB}$ of the Acts Interpretation Act 1901 (Cth).

The examination is to establish the underlying intent of the legislation, and the legislative interpretations presented in this paper. Although there has been research, and commentary, published as to the operations and provisions of the Acts, this examination will focus on the Explanatory Memoranda accompanying the bills in Parliament and the legislation.

In November 2011, the Gillard ALP government introduced the Clean Energy Act 2011 (Cth) (CE Act). The Explanatory Memorandum to the CE Bill, the Act itself and its accompanying legislation, expressly refer to it being a carbon-pricing mechanism, like a carbon tax, but not a carbon tax in itself. 
In addition, the Explanatory Memorandum expressly states the intention of the legislation was that, from 1 July 2015, the CE Act "mechanism will shift to a 'cap and trade' emissions trading scheme. In this second 'flexible charge' stage, the carbon price will be set by the market"10.

However, despite that express intention, it was regarded by some researchers, such as Dabner (2013), as a carbon tax. In addition, the legislation was commonly referred to by many political commentators and parliamentarians as Australia's carbon tax.

In 2014, the CE Act was repealed as a carbon tax by the Abbott Liberal government when the Clean Energy Legislation (Carbon Tax Repeal) Act 2014 (Cth) was passed in the Australian Parliament. Therefore since the repeal of the CE Act it is understandably considered that Australia no longer has a carbon tax (Crowley, 2017).

However, that may not be the case. Legislation introduced earlier, by the Howard Liberal government in 2000 - the Renewable Energy (Electricity) Act 2000 (Cth) (REE Act), has similar objectives, carries out a very similar purpose, and functions in a very similar way to the CE Act. Therefore if the CE Act is considered a carbon tax then the very similar, but considerably narrower, REE Act must also be considered a carbon tax.

To examine both Acts it is worthwhile to consider the similarities of their objectives and operations. Section 3 of the CE Act details a key objective of the CE Act. That was to

take action directed towards meeting Australia's long-term target of reducing Australia's net greenhouse gas emissions to $80 \%$ below 2000 levels by 2050;

and to do so in a way that

encourage [d] investment in clean energy,

Similarly, the objectives of the REE Act are prescribed in section 3 of that act and are:

a. to encourage the additional generation of electricity from renewable sources; and

$b$. to reduce emissions of greenhouse gases in the electricity sector; and

c. to ensure that renewable energy sources are ecologically sustainable.

In particular, the second objective of the REE Act also shares an identical purpose with one of those of the CE Act which states - "the underlying purpose of a carbon tax is to reduce emissions of carbon dioxide" (Australia, 2010).

The key difference between the CE Act and the REE Act is that the CE Act encompasses the burning of fossil fuels across all industries within the Australian economic sector and any other sources of greenhouse gas emissions. On the other hand the REE Act is specifically limited to reducing emissions of greenhouse gases from the electricity generation sector.

As with the CE Act, s 3 of the REE Act aims to achieve its objectives through the issuing of certificates for the generation of electricity using eligible renewable energy sources and requiring certain purchasers (called liable entities) to surrender a specified number of certificates for the electricity that they acquire during a year.

The provisions of the REE Act place an impost on electricity wholesalers, which sell electricity purchased from fossil fuelled electricity generators, to purchase registered certificates from renewable energy electricity producers.

The certificates are subsequently surrendered to the government for no financial exchange proportional to a ratio set by the government according to the volume of electricity generated from fossil fuel sources.

It should be clarified that despite an apparent 'rationing' or limitation being placed on volumes of electricity generated by way of fossil fuel, there is no limitation or 'cap' placed on electricity generation or greenhouse gas emissions resulting from that generation. The targets set under the REE Act and its regulations, are for the purpose of establishing rates of the number of certificates that must be surrendered, not to limit them by way of quotas or a cap on emissions. 
The REE Act should not be confused with a 'cap and trade' emissions reduction system. Therefore, it is considered that the surrendering of the REE Act certificates is a tax - a financial impost by a government, on its people, for no return.

Similarly, the CE Act required surrendering of 'carbon units' pursuant to the volume of emissions calculated to have been emitted by burning the fossil fuels listed in the Act. Under both pieces of legislation the process of surrendering certificates is made compulsory in that, should a liable party fail to surrender the specified number of certificates, it must pay a charge in lieu of any shortfall ${ }^{11}$.

The basis for calculating the number of certificates to be purchased, and surrendered, is established from the volume of electricity generated from "the burning of fossil fuels - coal, petroleum products such as petrol and aviation fuel, and natural gas" (Australia, 2010).

In similarity with the provisions of the CE Act, the REE Act is an impost on the creation of emissions produced from the burning of fossil fuels. Both place a cost on fossil-fuelled electricity generation. That impost is effectively "placing a cost on these negative externalities." (Australia, 2010). Therefore, the REE Act fulfils the criteria of a carbon tax in accordance with "the underlying purpose of a carbon tax [which] is to reduce emissions of carbon dioxide and thereby slow global warming" (Australia, 2010). The following section considers the definition of a tax. It places that definition within the framework of a carbon tax, and examines the REE Act to substantiate or refute the suggestion that the REE Act functions as a carbon tax. The REE Act is the legislative process that taxes greenhouse gas emissions produced by the generation of electricity by burning fossil fuel. Therefore, if the CE Act was described, and accepted, as a carbon tax, then, so too, can the REE Act be described as a carbon tax.

The REE Act may not be as broad in its provisions as are the provisions of the CE Act. Nonetheless, it fulfils the same purpose, and it functions in a very similar way, as did the CE Act. Therefore Australia retains a tax on carbon emissions. This is despite the general belief that the CE Act was the only Australian carbon tax, and that that tax was repealed in 2014 (Crowley, 2017).

The following section examines the CE Act in detail.

\section{Clean Energy Act 2011 (Cth)}

Despite the CE Act being repealed in 2014, it is nonetheless examined here, as for a time it made a significant contribution to Australia's carbon tax regime.

The Explanatory Memorandum to the Clean Energy Bill refers to it as being a carbon pricing mechanism, and states that it "will operate like a carbon tax." (Australia, 2011:29). That description tends to indicate that the Act may not have been intended to actually be a carbon tax. Further, the memorandum states, that in its proposed second stage, "from 1 July 2015, the mechanism will shift to a 'cap and trade'." (Australia, 2011:29).

That statement may cast doubt on the CE Act as being ultimately intended to be a carbon tax. However, be that as it may, legislators appeared to have removed doubt as to its compliance with the taxing provisions of The Australian Constitution.

The Explanatory Memorandum expressly states "The Commonwealth does not consider that the charges for the auction of carbon units amount to taxation. However, separate bills impose the charges so far as they are taxation to ensure that there can be no argument that there has not been compliance with section 55 of the [Australian] Constitution." (Australia, 2011:129). However, despite the inclusion of that paragraph in the Explanatory Memorandum, and while the memorandum to the Clean Energy Bill, the Act itself, and its accompanying legislation, do not expressly refer to the Act as being a carbon tax, commentators and researchers such as Dabner (2013) regard it as such.

In addition, a background note, issued by the Australian Parliament in November 2010, to its proposed CE Act, while not declaring the Act to be a Carbon Tax Act, defined a carbon tax in its statement that "A carbon tax is a tax on energy sources which emit carbon dioxide. It is a pollution tax, which some economists favour because they tax a 'bad' rather than a 'good' (such as income)." (Australia, 2010).

The same note continued to define a carbon tax as "[c]arbon taxes address a negative externality. Externalities arise when an individual production or consumption activity imposes costs or benefits on 
others. In market transactions, these costs and benefits are not normally reflected in the prices involved in the transaction, or taken into account in the transaction decision." (Australia, 2010). It further states that "[b]y placing a cost on these negative externalities the underlying purpose of a carbon tax is to reduce emissions of carbon dioxide and thereby slow global warming. It can be implemented by taxing the burning of fossil fuels - coal, petroleum products such as petrol and aviation fuel, and natural gas-in proportion to their carbon content." (Australia, 2010).

Section 3 of the CE Act details the objectives of the legislation.

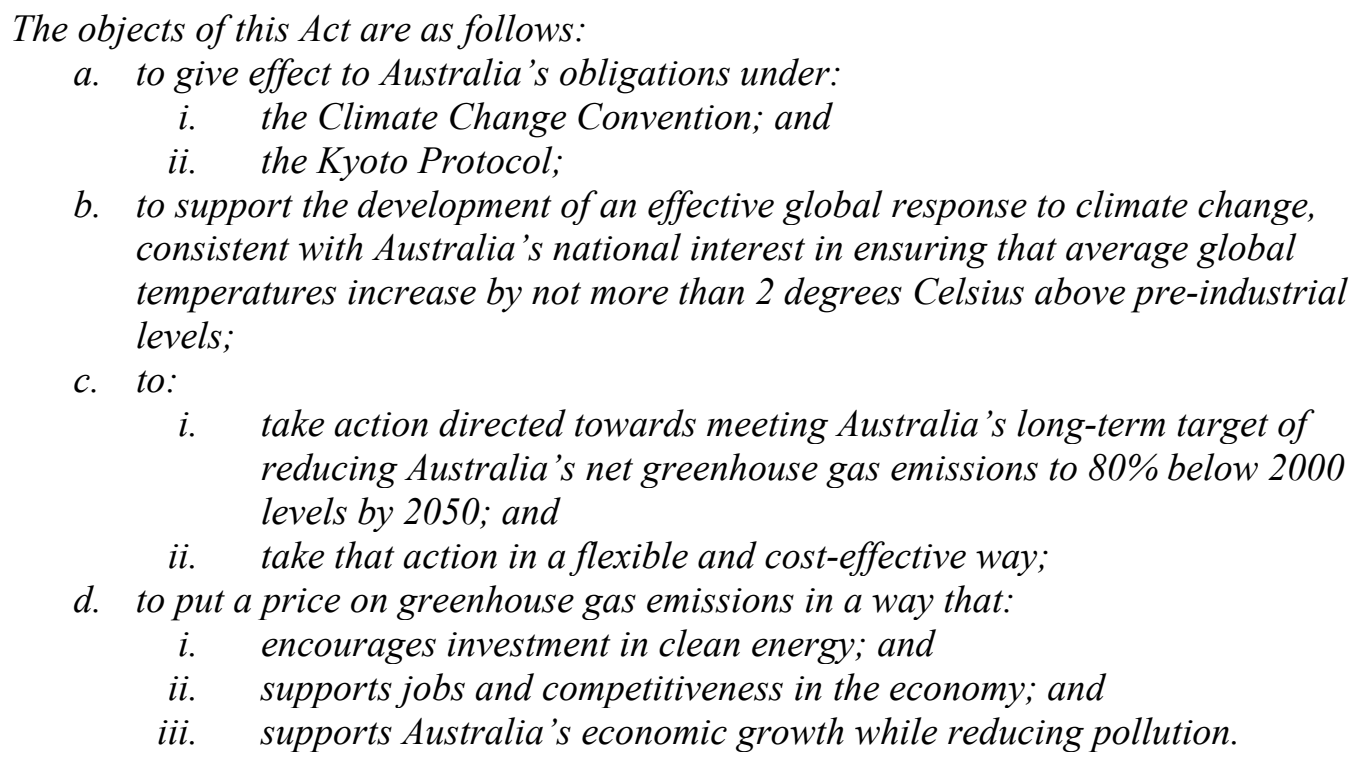

The objects clearly state that the purpose of the Act is to reduce greenhouse gas emissions to a specified level and to do that by moving towards 'clean energy'. The act refers to clean energy technology and clean energy investment plans but does not appear to define what 'clean energy' is. That discussion is beyond the scope of this paper but the omission is noted.

How the Act functioned is described in an information statement issued by the Clean Energy Regulator. It is reproduced below to provide an explanation of the administrative mechanism of the regulator.

\section{How did it work?}

Liable entities reported annually on their emissions or potential emissions in relation to the 2012-13 and 2013-14 financial years under the National Greenhouse and Energy Reporting Act 2007 (NGER Act). For each financial year, liable entities were required to surrender one eligible emissions unit for every tonne of carbon dioxide equivalent $\left(\mathrm{CO}_{2}-\right.$ e)-that they produced.

In 2012-13, carbon units could be purchased from the Clean Energy Regulator for a fixed price of $\$ 23$ per unit, and in 2013-14 carbon units could be purchased for $\$ 24.15$ per unit. If a liable entity did not surrender any or enough units, it incurred a 'unit shortfall charge'.

From 2012 to 2014, this charge was set at 130 per cent of the fixed price for the relevant financial year multiplied by the number of units is [the] shortfall. 
The unit shortfall charge created an incentive to surrender units under the mechanism rather than pay the higher unit shortfall charge.

The carbon pricing mechanism included systems for assessing liability for emissions, issuing free units to energy intensive trade exposed industries, meeting liability for emissions through payment and surrender processes for eligible emissions units, and relinquishing units (in certain circumstances units are returned to the Commonwealth without them being surrendered).

\section{How was liability decided?}

An entity was liable if it was responsible for one or more facilities that emitted covered scope 1 emissions of 25000 tonnes of carbon dioxide equivalent (CO2-e) or more in an eligible financial year (i.e. in 2012-13 or 2013-14). An entity was also liable if it supplied natural gas, imported, manufactured or produced liquefied petroleum gas or liquefied natural gas for non-transport use in an eligible financial year, or if it was an OTN [Obligation Transfer Number] holder that quoted its OTN in a way that gives rise to a liability. (Australian Government, 2015)

The overall operation was fairly simple: for every tonne of carbon dioxide emitted the emitter was required to surrender a 'carbon unit'. The carbon units were purchased from the regulator at an initial rate of $\$ 23$.

By comparing the operations of the CE Act with the definition of tax established above, the surrendering of the 'carbon units' was a yielding up of property, at the direction of the government, for no corresponding consideration or form in return. The legality of the CE Act was not challenged; nor was its cost challenged as extortionate; and it was not a fine or a penalty. Penalties under the CE Act were for non-compliance which satisfies the requirement that a tax be compulsory.

It appears therefore, that despite the provisions of ss 110, 111 stating that the CE Act was "not a law imposing taxation within the meaning of section 55 of the [Australian] Constitution". It was in fact, a tax based on the volume of greenhouse gases emitted to the atmosphere by a liable party. A tax placed on the emission of greenhouse gases has become known and is referred to as a 'carbon tax'.

Though it is beyond the scope of this paper, it is noted that in order to maintain energy security, concessions were granted to coal-fired electricity generators ${ }^{13}$. However, those concessions were only for the first three years of the operation of the CE Act, and the Act was clearly intended to apply for around 40 years.

However the CE Act was short-lived. It did not revert to a 'cap and trade system', planned for 1 July 2015. The Federal government changed, and the CE Act was repealed in 2014. Therefore, as far as the Parliament and the general population of Australia were concerned, the 'carbon tax' was at an end.

The following section examines the REE Act which is also aimed at reducing atmospheric greenhouse gas emissions through a very similar process to the provisions of the CE Act. It aims to establish if that REE Act is a tax based on the volumes of greenhouse gases emitted by fossil fuelled electricity, and is therefore a carbon tax.

\section{Renewable Energy (Electricity) Act 2000 (Cth)}

The REE Act remains in force in 2019. The purpose of this examination is to establish if the Act functions as, and should be considered as, a carbon tax.

While the objectives of the REE Act are quite broad, the Act is relatively narrow. Unlike the CE Act, which applied to all energy users and emitters, the REE Act applies specifically to large electricity generators only ${ }^{12}$.

The objectives of the REE Act are contained in s 3 of the Act and are:

a. to encourage the additional generation of electricity from renewable sources; and 
b. to reduce emissions of greenhouse gases in the electricity sector; and

c. to ensure that renewable energy sources are ecologically sustainable.

This is done through the issuing of certificates for the generation of electricity using eligible renewable energy sources and requiring certain purchasers (called liable entities) to surrender a specified number of certificates for the electricity that they acquire during a year.

Where a liable entity does not have enough certificates to surrender, the liable entity will have to pay renewable energy shortfall charge.

An exemption relating to one or more emissions-intensive trade-exposed activities may be taken into account in working out a liable entity's renewable energy certificate shortfall for a year. If it is, it will reduce the renewable energy shortfall charge otherwise payable.

The objectives of the REE Act are in very similar to those stated in a background note issued by the Australian Parliament, in November 2010, to the then proposed CE Act. That note states that " $[\mathrm{b}] \mathrm{y}$ placing a cost on these negative externalities the underlying purpose of a carbon tax is to reduce emissions of carbon dioxide and thereby slow global warming. It can be implemented by taxing the burning of fossil fuels - coal, petroleum products such as petrol and aviation fuel, and natural gas-in proportion to their carbon content." (Australian Government, 2015).

Therefore, while the CE Act, discussed in the preceding section, is far broader than the narrow tax base of the REE Act, both are focussed on reducing greenhouse gas emissions and in particular those emitted from burning fossil fuel.

However the operation of the REE Act does not require the payment of tax directly to the government, and thereby providing government revenue. Rather, s 8 of the REE Act imposes an obligation on large electricity wholesales to purchase 'renewable energy certificates' from 'accredited renewable energy generators'.

The renewable energy certificates are divided into two categories:

a. large-scale generation certificates (LGCs), which are created in relation to the generation of electricity by accredited power stations; and

b. small-scale technology certificates (STCS), which are created in relation to the installation of solar water heaters and small generation units.

The certificates are then surrendered by the wholesalers of electricity to the government according to a ratio based on the volume of electricity purchased set by the government. That ratio is set in accordance with the government's renewable energy target (RET) for the particular year of operation.

Detailed discussion of how the ratio is set is beyond the scope of this paper, however to illustrate, the number of certificates required to be surrendered the rates for 2013 is considered. For the year 2013 the renewable power percentage to achieve the renewable energy target for that year was 10.65 LGCs per 100 MWh of electricity purchased. To that was added the small-scale technology percentage of 19.70 STCs per $100 \mathrm{MWh}$.

The combined tax rate is expressed in renewable energy credits and not in monetary terms. The actual fiscal cost of the tax is subject to the market forces which establish the trade price of the renewable energy credits (tax tokens) surrendered in order to 'pay the tax'.

The tax mechanism, therefore, also functions as a subsidy to renewable energy generators from whom the renewable energy credits are purchased, as illustrated in Figure 3 above. The RET is a matter of considerable parliamentary and social debate. It is set each year and has been extremely volatile.

More importantly, the RET is a method of setting a ratio of non-polluting renewable energy generated electricity to fossil fuel based generation plant. It is not a ceiling or cap on emissions beyond which a penalty is paid. A ceiling or cap on emissions is analogous to a highway speed limit beyond which a motorist suffers a fine for exceeding the speed limit. 
To add complexity to the cost of the renewable energy certificates, and therefore the fiscal tax rate to electricity sales, the price of the renewable energy credits is subject to open market forces and traded prices can vary widely.

The value of the small-scale technology certificates has a maximum floor price of $\$ 40$ established by a government trading house, but the price of the large-scale generation certificates is entirely dependent on the economic factors of supply and demand. There is an upper limit assumed to exist, being the taxeffective value of the 'shortfall penalty charge' of $\$ 65$ which is not tax deductible.

The 'tax-effective' value of a renewable energy certificate purchased to avoid a penalty is governed by the prevailing company tax rate and which was $\$ 92.86$ in October 2017 . The market price for largescale generation certificates has approached to near that level, but is yet to reach $i^{14}$. To date very few liable parties have chosen to pay the shortfall penalty in lieu of purchasing and surrendering the requisite renewable energy certificates.

It is considered that the 'yielding up' of property in the form of renewable energy certificates is a tax. As the REE Act applies to the sale of electricity, it is specifically considered to be a tax on a good, and is therefore an excise. It is a tax on pollution and can therefore be classified as an environmental tax. Finally, as illustrated in Figure 4, it is a tax on greenhouse gas emissions and can be further categorised as a carbon tax.

Further, the excise revenue is hypothecated to subsidise the burgeoning renewal energy industry. The central purpose of the subsidy is to replace the green house gas emitting, fossil fuel based, electricity generation power stations of the $19^{\text {th }}$ and $20^{\text {th }}$ Centuries, with non-polluting, renewable energy sourced electricity generation which has been developed to an industrial application in the late $21^{\text {st }}$ century.

\section{SUMMARY AND CONCLUSION}

Despite the repeal of the CE Act in 2014, Australia continues to have a form of carbon tax. Further, it has had that carbon tax legislation in operation since 2000. It is the REE Act, and that is the legislative process that taxes greenhouse gas emissions produced by the generation of electricity by burning fossil fuel.

The provisions of the REE Act may not be as broad of the provisions of the CE Act, but it fulfils the same purpose and functions in a very similar way. Given that the CE Act was accepted and considered a carbon tax, the REE Act must therefore also be considered to be a carbon tax. Though the payments are is not directed to the government, they are, nonetheless, directed by the government.

Specifically, it is concluded that the REE Act is a tax on a good - electricity. Therefore the function of the Act is that of an excise, and the Australian Government has the right to impose excises.

Further, as that excise is passed directly to the renewable energy industry, the tax is effectively hypothecated, or reserved, to act as a subsidy to the burgeoning renewal energy industry. The subsidy helps to provide economic sustainability to the renewable energy based electricity generation industry, and meets the key objectives of the REE Act, and in particular of that of s 3 "to reduce emissions of greenhouse gases in the electricity sector".

\section{ENDNOTES}

1. 1 January 1900; Commonwealth of Australia Constitution Act 1900 (Imp) 63 \& 64 Vict, c 12. (The Australian Constitution) s 51 (ii).

2. Criminal Code Act 1913 (WA) s 371.

3. Reference contained in Burton: Federal Commissioner of Taxation v Spotless Services Ltd (1996) 186 CLR 404.

4. Reference contained in Burton: See, for example, Eric Mack, 'Self Ownership, Taxation, and Democracy: A Philosophical-Constitutional Perspective' in Donald P. Racheter and Richard E. Wagner, Limiting Leviathan, Edward Elgar, Cheltenham, 1999, ch 2; for discussion of this discourse see: Marc Linder, 'Eisenhower-Era Marxist Confiscatory Taxation: Requiem for the Rhetoric of Rate Reduction for the Rich' (1996) 70 Tulane Law Review 905. 
5. (1984) 158 CLR 622; 84 ATC 4230 at CLR pp 639-641, ATC pp 4236-4237; cf per Brennan J at CLR p 649, ATC p 4242.

i $\quad$ Citing Matthews v Chicory Marketing Board (Vic) (1938) 60 CLR 263.

ii $\quad R v$ Barger (1908) 6 CLR 41, per Isaacs J at pp 97-99.

iii Not only must it be possible to point to the criteria themselves, but it must be possible to show that the way in which they are applied does not involve the imposition of liability in an "arbitrary or capricious manner ...": FC of T v Hipsleys Ltd (1926) 38 CLR 219 at p 236.

iv. MacCormick v FC of T (1984) 158 CLR 622; 84 ATC 4230, per Gibbs CJ, Wilson, Deane and Dawson JJ at CLR p 639, ATC p 4236 cf per Murphy J at CLR pp 644-646, ATC pp 4239-4240.

6. Commonwealth of Australia Constitution Act 1900 (Imp) 63 \& 64 Vict, c 12. (The Australian Constitution).

7. Stern notes: Continuous trading is necessary to ensure a common price between auctions/allocations.

8. Stern notes: To the extent that firms are able to pass on to consumers the increase in marginal production costs, a system with free quotas may be regressive (because shareholders tend to be wealthier than the general population).

9. Stern notes: Where the ultimate incidence of the tax falls on customers, they pay a price for carbon but there is no benefit to the wider revenue base.

10. Explanatory Memorandum, Clean Energy Bill 2011 (Cth) 29.

11. 'Where a liable entity does not have enough certificates to surrender, the liable entity will have to pay renewable energy shortfall charge.' Renewable Energy (Electricity) Act 2000 (Cth) s 3; 'If a person is responsible for covered emissions of greenhouse gas from the operation of a facility, the facility's annual emissions are above a threshold, and the person does not surrender one eligible emissions unit for each tonne of carbon dioxide equivalence of the gas, the person is liable to pay unit shortfall charge.' Clean Energy Act (Cth) s 4.

12. The provisions of the Act apply to wholesale purchasers of electricity delivered to a grid with a capacity of 100MW or more. Renewable Energy (Electricity) Act 2000 (Cth) s 31.

13. Clean Energy Act 2011 (Cth) pt 8.

14. On 12 October 2017 the spot price for LGC market trades was $\$ 83.25$ with no trades taking place. Figure courtesy of TFS Green Melbourne Australia. Email from Marco Stella to Lex Fullarton, 12 October 2017.

\section{REFERENCES}

Air Caledonie International v The Commonwealth (1988). 165 CLR 462.

Allan, C. M. (1971). The Theory of Taxation as cited in Woellner et al, 1997 Australian Taxation Law (CCH, 7th ed, 1997).

Australia (2011). Explanatory Memorandum. Clean Energy Bill 2011 (Cth).

Australian Government (2015). Clean Energy Regulator. Carbon Pricing Mechanism: About the Mechanism. Retrieved August 31, 2017, from http://www.cleanenergyregulator.gov.au/Infohub/CPM/About-the-mechanism

Australia, Parliament (2010). Department of Parliamentary Library. Carbon Taxes. Retrieved August 31, 2017, from

http://www.aph.gov.au/About_Parliament/Parliamentary_Departments/Parliamentary_Library/Br owse_by_Topic/ClimateChangeold/responses/economic/carbontax

Bartlett v Commissioner of Taxation (2003). FCA 1125.

Burton, M. (2007). Responsive Regulation and the Uncertainty of Tax Law - Time to Reconsider the Commissioner's Model of Cooperative Compliance? eJournal of Tax Research, 5(1), 71.

Retrieved November 15, 2017, from <https://www.business.unsw.edu.au/researchsite/publications-site/ejournaloftaxresearch-site/Documents/paper4_v5n1.pdf

Butt, P., et al. (eds). (2004). Butterworth's Concise Australian Legal Dictionary. LexisNexis, $3^{\text {rd }}$ ed. Capital Duplicators Pty Ltd v Australian Capital Territory (No2) (1993). 173 CLR 561.

Clean Energy Act 2011 (Cth).

Clean Energy Legislation (Carbon Tax Repeal) Act 2014 (Cth).

Commonwealth of Australia Constitution Act 1900 (Imp) 63 \& 64 Vict, c 12. (The Australian Constitution.) 
Criminal Code Act 1913 (WA).

Crowley, K. (2017). 'Up and Down With Climate Politics 2013-2016: the repeal of carbon pricing in Australia'. 8 Wires Climate Change. Retrieved November 6, 2017, from http://onlinelibrary.wiley.com/doi/10.1002/wcc.458/epdf

Dabner, J. H. (2013). 'You're Gunna Get Wacked!' The Political Economy of the Australian Carbon and Mining Tax Reforms. Social Science Research Network. Retrieved August 26, 2017, from https://papers.ssrn.com/sol3/papers.cfm?abstract_id $=2701028$

Deustch, R. L., et al. (2017). Australian Tax Handbook 2017. (Thomson, 2017) para 1020.

Email from Marco Stella to Lex Fullarton (2017, October 12). LGC market trades.

Federal Commissioner of Taxation v Hipsleys Ltd (1926). 38 CLR 219.

Federal Commissioner of Taxation v Spotless Services Ltd (1996). CLR 404.

Income Tax Assessment Act 1997 (Cth).

Mac Cormick v Federal Commissioner of Taxation (1984). 158 CLR 622.

Matthews v Chicory Marketing Board (Vic) (1938). 60 CLR 263.

Melbourne University Law Review (2018). Australian Guide to Legal Citation, $4^{\text {th }}$ ed.

McKechnie, J. L. (ed). (1956). Webster's New Twentieth Century Dictionary of the English Language Unabridged. World Publishing.

Morabito, V., \& Barkoczy, S. (1996). What is a Tax? The Erosion of the "Latham Definition". 6 Revenue Law Journal, 43.

Renewable Energy (Electricity) Act 2000 (Cth).

R v Barger (1908). 6 CLR 41, per Isaacs J at pp 97-99.

Stern, N. H. (2007). The Economics of Climate Change: The Stern Review. Cambridge.

Stevenson, A. (ed). (2007). Shorter Oxford English Dictionary: On Historical Principles. Oxford, 6th ed.

Weber, R. H. (2011). Innovative Taxation Strategies Supporting Climate Change Resilience' in Larry Kreiser, et al (eds), Environmental Taxation and Climate Change: Achieving Environmental Sustainability through Fiscal Policy, 47.

Woellner, R., et al. (1997). Australian Taxation Law. CCH, 7th ed.

Yallop, C., et al. (eds). (2006). Macquaire Concise Dictionary. Macquarie Library, $4^{\text {th }} \mathrm{ed}$. 